\title{
Fate of Phaeodactylum tricornutum and nitrogen flow in an experimental microbial food web limited at the top by protozoans
}

\author{
France Van Wambeke* \\ Microbiologie Marine, C.N.R.S., U.P.R. 223, Case 907, Campus de Luminy, F-13288 Marseille Cedex 9, France
}

\begin{abstract}
The fate of phytoplankton nitrogen through a simplified microbial food web was investigated. In a 2-stage culture system, I separated production and degradation processes of a diatom, Phaeodactylum tricornutum. In the first stage, the algae grew axenically and continuously. In the second stage, maintained in the dark, a $20 \mu \mathrm{m}$ ciliate grazed on the diatoms and constituted the last trophic step. A microbial loop, based on bacterial utilization of partially degraded $P$. tricornutum cells, egested with the ciliate digestive vacuoles, developed rapidly. Ciliate production was maintained only because the $P$. tricornutum grazer was able to feed simultaneously on bacterivorous nanoflagellates, themselves preying upon bacteria using egested material of the ciliate. Dissolved organic nitrogen rapidly constituted more than $50 \%$ of the identified nitrogen forms (dissolved + particulate; mineral + organic). The nitrogen budget compiled during the succession of the different prey-predator relationships revealed the important role of dissolved organic matter adsorption on particles and aggregate formation including unstable organic colloids. The temporary importance and turnover of colloidal nitrogen was thus demonstrated.
\end{abstract}

KEY WORDS: Dissolved organic nitrogen - Microbial loop $\cdot$ Phaeodactylum tricornutum Ciliate

\section{INTRODUCTION}

The concept of the microbial loop (Azam et al. 1983) has brought new interest to the studies of composition and utilization of dissolved organic matter (DOM) in aquatic environments. Of primary production, 10 to $50 \%$ is transformed into bacterial biomass, channelled to the microbial loop, and subsequently transferred to higher trophic levels through the grazing food chain (Cole et al. 1988). Besides phytoplankton exudates (Baines \& Paice 1991), digestive by-products of grazing could also constitute a source of DOM for heterotrophic bacteria (Jumars et al. 1989). In addition to DOM, interest has recently been focused on dissolved organic nitrogen (DON). The vertical distribution of DON, with high concentrations near the surface where mineral nitrogen sources are limited (Karl et al. 1993, Koike et al. 1993), suggests that DON should play an

•E-mail: micromar@riou.univ-mrs.fr important role in the nitrogen cycle in the euphotic zone. For example, ammonium is generally described as the main nitrogen form in excretion processes of microzooplankton (Glibert 1982, Paashe \& Kristiansen 1982). But dissolved free amino acids (Andersson et al. 1985 ) and dissolved combined amino acids (Nagata \& Kirchman 1991) are also produced by protozoans. DON needs now to be included to balance nitrogen budgets (Glibert 1988, Nagata \& Kirchman 1991).

In the euphotic zone, phytoplankton production and loss occur simultaneously. These processes are so tightly coupled that the fate and the turnover of phytoplankton-derived detritus (particulate nitrogen or DON) through microbial food webs are difficult to estimate. Thus, I designed an experiment which allowed the degradation of phytoplanktonic material to be studied separately from production processes, with a 2 -stage linked culture system (Güde 1991). The objective of this study was to follow the fate of phytoplankton nitrogen in a simple microbial food web limited at 
the top by a ciliate. Through the investigation of trophic links and the nitrogen budget, I examined importance of colloidal nitrogen.

\section{MATERIALS AND METHODS}

Culture conditions. The 2-stage culture system was constructed as shown in Fig. 1. Exudates and cellular content of phytoplankton vary widely with species and phases of growth. Thus, to maintain a constant algal production in the first stage (producing stage ' $\mathrm{P}$ '), a steady-state growth of Phaeodactylum tricornutum algae was controlled in a continuous culture (Van Wambeke unpubl.). P. tricornutum was grown axenically in $\mathrm{N}$-replete conditions in a $5 \mathrm{l}$ culture vessel under continuous light. The medium reservoir was filled with Whatman GF/F pre-filtered sea water supplemented with $50 \mu \mathrm{M} \mathrm{N}-\mathrm{NO}_{3}, 5 \mu \mathrm{M} \mathrm{P}_{-} \mathrm{PO}_{4}$ and $30 \mu \mathrm{M}$ Si-silicate, then autoclaved. This medium was also supplemented with vitamins and metals (Antia and Cheng's medium diluted at $1 / 10$, without Tris). The axenic culture was maintained at a dilution rate of $0.5 \mathrm{~d}^{-1}$ with the medium inflow of $2.5 \mathrm{I} \mathrm{d}^{-1}$ and a continuous outflow of the biomass and excretion products of the first stage culture vessel of $2.5 \mathrm{l} \mathrm{d}^{-1}$. This system maintained constant growth of the prey and avoided influence of its nutritional state on nitrogen regeneration (Goldman et al. 1985).

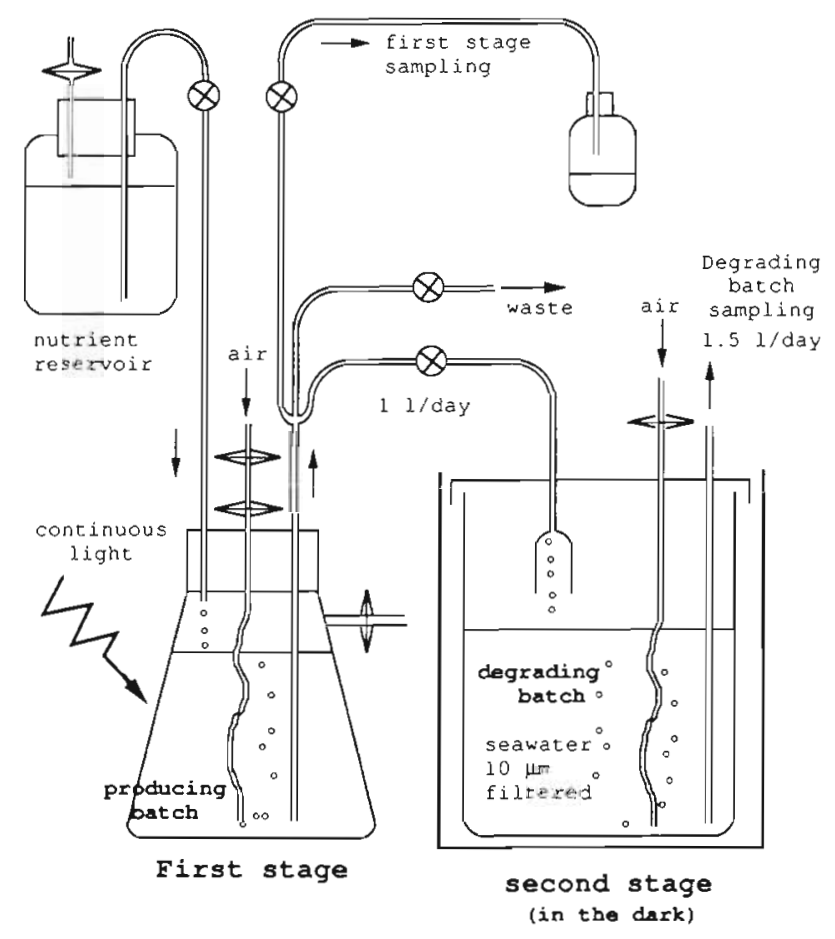

Fig 1. The 2-stage culture system
The outflow was partly used for first stage samples. Another part of the outflow was dispensed drop by drop (average $1 \mathrm{ld}^{-1}$ ) into a plastic enclosure. This second stage contained 74 l natural sea water (Gulf of Marseille, France), firstly filtered by gravity through a $150 \mu \mathrm{m}$ nylon mesh, and then filtered again through a $10 \mu \mathrm{m}$ Nuclepore filter of $47 \mathrm{~mm}$ diameter under low vacuum pressure. Aeration and agitation of this second stage (degrading stage ' $D$ ') were provided by blowing air into the microcosm. Water temperature increased from 18 to $21^{\circ} \mathrm{C}$ during the experiment which lasted about 1 mo. The degrading stage was permanently kept in the dark to avoid any new phototrophic production. Approximately $1.5 \mathrm{l}$ was collected every morning by a siphon tube for all analyses.

Microbial counts. Algae, heterotrophic nanoflagellates (HNAN) and bacteria were fixed with formalin (final concentration $2 \%$ ), and stained with DAPI. Bacteria were filtered through $0.2 \mu \mathrm{m}$ Nuclepore filters and counted (Porter \& Feig 1980). Algae and heterotrophic nanoflagellates were filtered through $0.8 \mu \mathrm{m}$ Nuclepore filters and counted (Sherr \& Sherr 1983). Sea water subsamples were fixed with Lugol's solution and ciliates were counted using Utermöhl's sedimentation technique.

Nitrogen conversion factors. Nitrogen conversion was estimated as follows:

Phaeodactylum tricornutum: The first stage outflow was regularly sampled for counts and particulate nitrogen analysis. The average nitrogen content of algae in the first stage outflow was $1.09 \mathrm{pg} \mathrm{N} \mathrm{cell}^{-1}$.

Ciliates and flagellates: Nitrogen equivalent was calculated from abundance and biovolume $\left(306 \mu^{3}\right.$ for HNAN and $8615 \mu \mathrm{m}^{3}$ for a ciliate, see 'Results') using

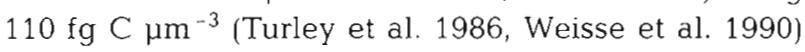
and a $\mathrm{C} / \mathrm{N}$ (by atom) ratio of 7 (Goldman et al. 1987a).

Bacteria: As this experiment provided no data on bacterial biovolume, I used Lee and Fuhrman (1987) conversion factors of $20 \mathrm{fg} \mathrm{C}$ bacterium $^{-1}$, with a $\mathrm{C} / \mathrm{N}$ ratio (by weight) of 4

Chemical analysis. After filtration through $0.2 \mu \mathrm{m}$ cellulose acetate filters (Millipore), sea water samples were kept frozen until nutrients were measured using a Technicon Analyzer, except for ammonium, which was immediately determined. All the parameters were measured according to Strickland \& Parsons (1972).

Dissolved free amino acids (DFAA) were analyzed by high performance liquid chromatography. The precolumn derivatization method with o-phthaldialdehyde (Lindroth \& Mopper 1979) was applied as previously described (Hermin et al. 1986). Dissolved organic nitrogen (DON) was determined in the $0.2 \mu \mathrm{m}$ Millipore filtrate by the UV- $\mathrm{H}_{2} \mathrm{O}_{2}$ oxidation method (Armstrong et al. 1966). DON was calculated from the difference between nitrate concentration in the UV 
treated sample and dissolved inorganic nitrogen concentration $\left(\mathrm{NO}_{3}+\mathrm{NO}_{2}+\mathrm{NH}_{4}\right)$ in the unaltered sample. Ammonium concentration was measured only after Day 10. Therefore, before this date, the method provided the sum DON $+\mathrm{NH}_{4}$, and not only DON. Nonidentified organic nitrogen corresponded to DON minus DFAA nitrogen after Day 10 , and (DON $\left.+\mathrm{NH}_{4}\right)$ minus DFAA nitrogen before. Particulate organic nitrogen and carbon were measured with a Perkin Elmer 240 Elemental Analyzer on samples retained on pre-combusted Whatman GF/F glass fiber filters.

Data analysis. In the degrading stage, the continuous inflow of $1 \mathrm{ld}^{-1}$ from the first stage did not correspond to the daily outflow ( $1.5 \mathrm{l}$ sample). The turnover rate of the water in such a system varied from 1.4 to $2 \% \mathrm{~d}^{-1}$.

Daily concentration variations of any component $C$ (nutrient, amino acid, cell), as calculated by simple difference between observed data (units $1^{-1}$ ), simultaneously reflected the sum of inflow fluxes, outflow flux and a term $K$, which corresponds to the sum of biological and physical fluxes inside the culture, i.e. the sum of production sources minus the sum of losses, and consequently represents the true net daily variation. $K$ was calculated as follows:

$$
K_{i j}(C)=\left(C_{j}^{\mathrm{D}}-C_{j}^{\mathrm{D}}\right) /(j-i)+\left(1.5 / V_{i j}\right) \times C_{i j}^{\mathrm{D}}-\left(1 / V_{i j}\right) \times C_{i j}^{\mathrm{p}}
$$

where $K_{r j}(C)$ was the daily net variation of $C$ in the degrading stage between days $i$ and $j$ (units $\mathrm{l}^{-1} \mathrm{~d}^{-1}$ ), $C_{j}^{\mathrm{D}}$ and $C_{i}^{\mathrm{D}}$ were the concentrations of the considered compound $C$ in the degrading stage (units $1^{-1}$ ) on days $j$ and $i$, respectively, $C_{i j}{ }^{\mathrm{P}}$ and $C_{i j}{ }^{\mathrm{D}}$ the average concentration of $C$ in the producing and in the degrading stage (units $l^{-1}$ ) between days $i$ and $j$, and $V_{i j}$ the degrading batch volume (l) between days $i$ and $j$. For average estimates, interpolation was assumed linear

Considering a single prey-predator link, instantaneous (daily) ingestion rates $(I)$ of a prey $(X)$ and byvolume gross growth efficiency $(Y)$ of a predator $(Z)$ can be estimated using calculated daily net variation if they approach the true production and clearance of the prey and predator, respectively, by the following equations:

$$
I_{i j}=K_{i j} X / Z_{i j}
$$

where $Z_{i j}$ (cells $1^{-1}$ ) is the average number of predators between days $i$ and $j$, and the daily net variation $K_{i j} X$ corresponds to the clearance rate of the prey (cells ${ }^{-1}$ $\left.\mathrm{d}^{-1}\right)$; and

$$
Y=\left(K_{1 j} Z / K_{j j} X\right) \times(\operatorname{vol} Z / \operatorname{vol} X) \times 100
$$

where vol $Z$ and $\operatorname{vol} X\left(\mu \mathrm{m}^{3}\right)$ are the volumes of the predator and prey, respectively. The daily net variation $K_{i} Z$ is the production rate of the predator (cells $\mathrm{l}^{-1} \mathrm{~d}^{-1}$ ). The Phaeodactylum tricornutum cell, with average di- mensions of $27 \times 2.5 \mu \mathrm{m}$, is considered as 2 cones joined at their bases. The calculated corresponding volume (vol $P$ ) was $45 \mu^{3}$, in the range of those classically used for this alga: 38.5 to $59.9 \mu^{3}$ (Bonin et al. 1986).

\section{RESULTS}

\section{Microbial populations}

A ciliate population preying on Phaeodactylum tricornutum developed rapidly in the degrading stage and constituted the higher trophic level. Ciliates increased from nondetectable levels to 250 ciliates $\mathrm{ml}^{-1}$ on Day 18 (Fig. 2b). This ciliate population appeared homogenous: the typical form of the cell was an ellipsoid of average linear dimensions $22.5 \times 32.5 \mu \mathrm{m}$ (biovolume was $8615 \mu^{3}$ ), morphologically similar to the oligotrich ciliate Strombidium sp. The first increase in algae numbers, from Days 2 to 5 , corresponded to the continuous inflow from the producing batch of about 8000 algae $\mathrm{ml}^{-1} \mathrm{~d}^{-1}$. Then algae numbers decreased to $420 \mathrm{ml}^{-1}$ on Day 11. From Days 5 to 10 , daily net disappearance of $P$. tricornutum cells varied from 4300 to 25600 algae $\mathrm{ml}^{-1} \mathrm{~d}^{-1}$. A second predator-
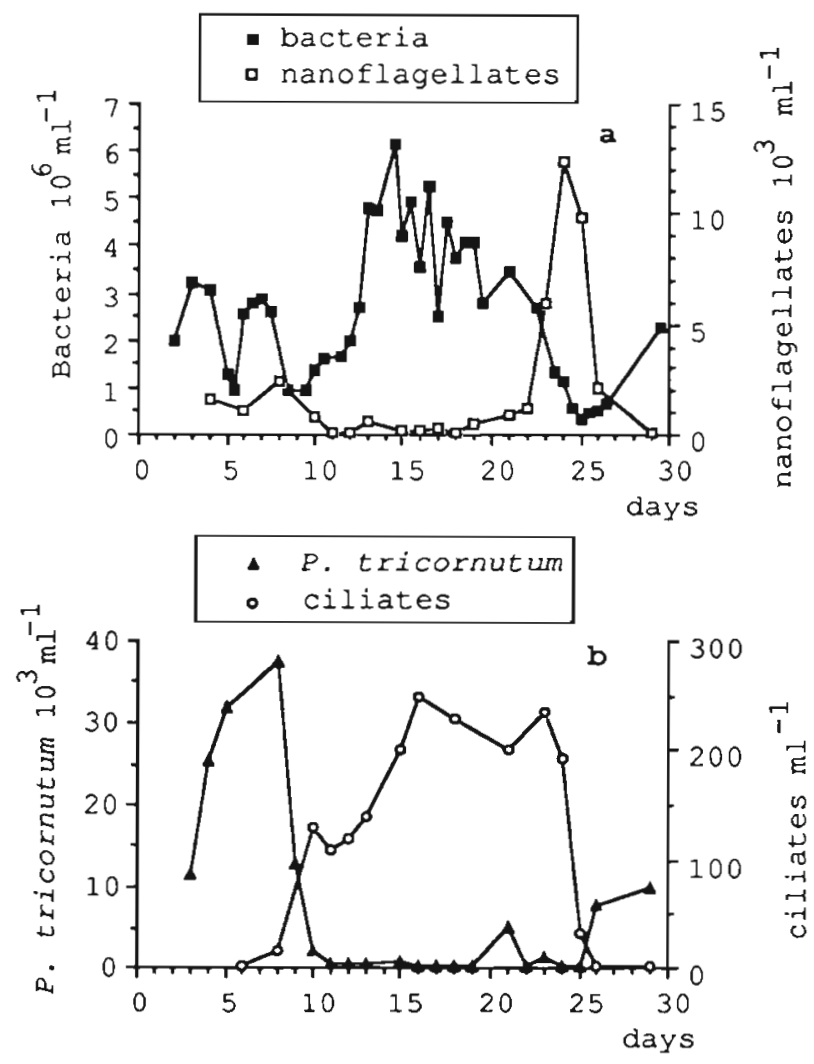

Fig. 2. Microbial populations. (a) Bacteria, heterotrophic nanoflagellates. (b) Phaeodactylum tricornutum, ciliates 
prey relationship was then observed between bacteria and heterotrophic nanoflagellates (Fig. 2a). Microscopic study revealed that the latter category included different species, principally of 3 size classes: $12-14 \times$ $8-9 \mu \mathrm{m}, 7-9 \times 5 \mu \mathrm{m}$, and spherical with $8-9 \mu \mathrm{m}$ diameter. An HNAN peak was observed at the end of the experiment, with a maximum at $12300 \mathrm{HNAN} \mathrm{ml}^{-1}$.

Instantaneous ingestion rates and gross growth efficiencies of the ciliate were calculated as abundance was increasing. Ingestion rate progressively decreased from 609 (Days 6 to 8 ) to 40 (Days 16 to 17) Phaeodactylum tricornutum cells ciliate ${ }^{-1} \mathrm{~d}^{-1}$ and then stabilized. The corresponding gross growth efficiencies by volume, calculated assuming an exclusive diet on $P$. tricornutum, increased from $23 \%$ on Day 7 to physiologically unrealistic values, i.e. $95 \%$ on Day 15 . Consequently the ciliates fed progressively on mixed sources, the alternative prey being heterotrophic nanoflagellates and, additionally, some large or clumped bacteria.

\section{Nutrients}

In the degrading batch, dissolved phosphate regularly increased from 0.08 to $1 \mu \mathrm{M}$ in $21 \mathrm{~d}$ (Fig. 3a). A

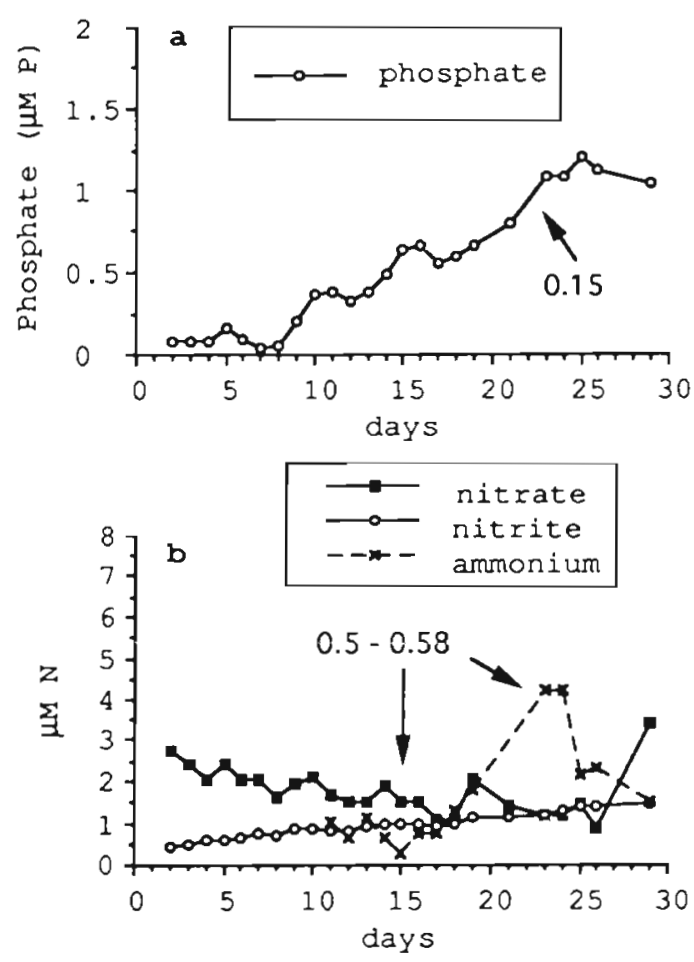

Fig. 3. Nutrients. (a) Phosphate and (b) nitrate, nitrite, ammonium concentrations in the degrading stage. Arrows show higher regeneration phases of phosphate and ammonium (net estimation, values indicated in $\mu \mathrm{mol} \mathrm{l} \mathrm{l}^{-1} \mathrm{~d}^{-1}$ ) calculated with daily corrected variations of these nutrients peak of ammonium was observed on Days 23 to 24 (Fig. 3b). To determine whether this increase in concentration was due to biological regeneration in situ or methodological artifact (enrichment from inflow, evaporation), I calculated daily corrected variations. In most cases there was net dissolved phosphorus production,

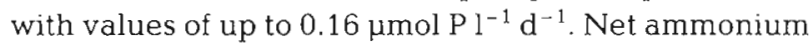
production rates attained $0.58 \mu \mathrm{mol} \mathrm{NH}_{4}-\mathrm{N} \mathrm{l}^{-1} \mathrm{~d}^{-1}$. A progressive accumulation of nitrite was observed. Average daily corrected variation was $0.044 \mu \mathrm{mol}$ $\mathrm{NO}_{2}-\mathrm{N}^{-1} \mathrm{~d}^{-1}$.

\section{Dissolved organic nitrogen}

DON tended to accumulate in the degrading stage, with a peak (30 $\mu \mathrm{M} \mathrm{N}$; Fig. 4a) on Day 13. DFAA showed a long period of accumulation from Days 8 to 16 (Fig. $4 \mathrm{a}$ ). This period corresponded to net production of DFAA nitrogen, as confirmed by positive values of corrected daily variations (Fig. 4b). This DFAA nitro-

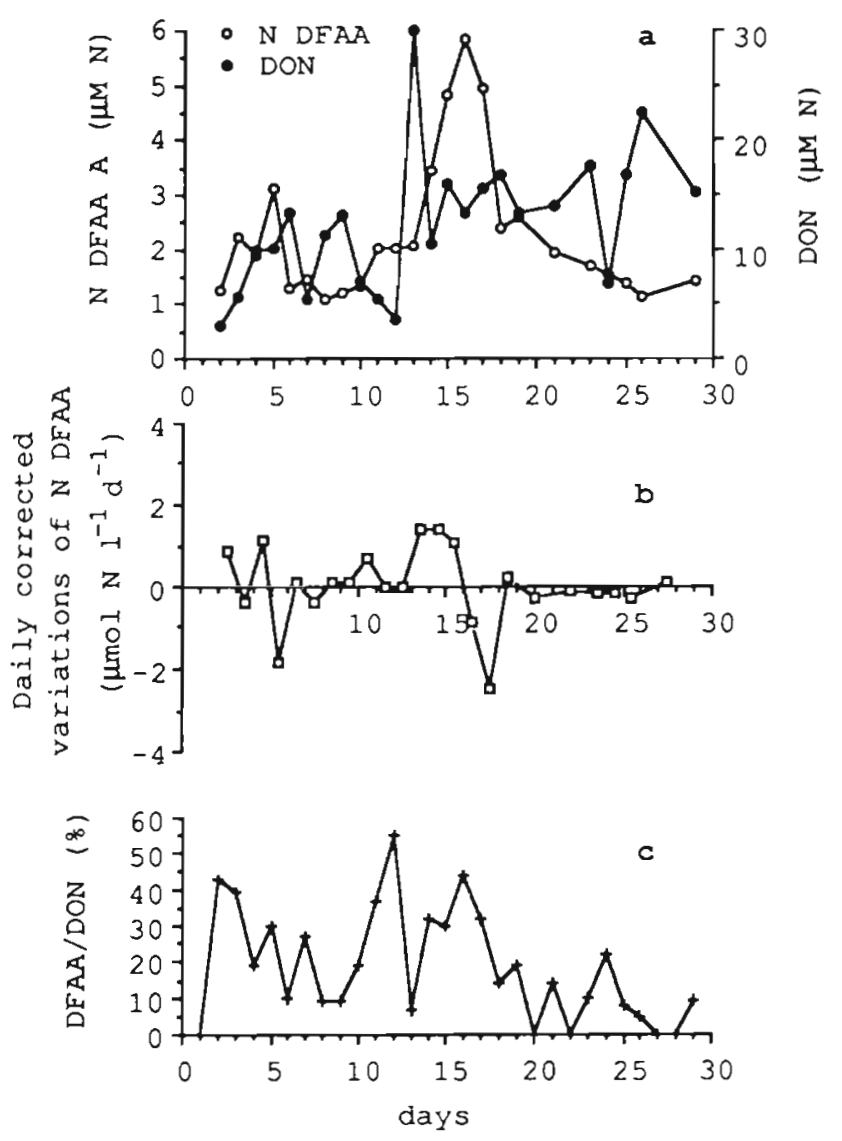

Fig. 4. (a) Dissolved free amino acid nitrogen (N DFAA), dissolved organic nitrogen (DON, $\mu \mathrm{M} N$ ). (b) Daily corrected variations of $\mathrm{N}$ DFAA ( $\mu$ mol $\left.\mathrm{N}^{-1} \mathrm{~d}^{-1}\right)$. (c) N DFAA/DON ratio $(\%)$ in the degrading batch 
gen peak followed the sudden increase of DON observed on Day 13. DFAA nitrogen/DON ratios reached values of up to $55 \%$ (Day 12; Fig. 4c).

\section{Nitrogen budget}

A nitrogen budget was established in the degrading batch, where all living microorganisms were counted. All nitrogen compartments were pooled for each daily sampling (Fig. 5) to provide total nitrogen values. In this batch, particulate detrital nitrogen (PDN) was calculated as:

$$
\begin{aligned}
\text { PDN }= & \text { PON }-(\text { bacterial } \mathrm{N}+\text { Phaeodactylum } \\
& \text { tricornutum } \mathrm{N}+\text { ciliate } \mathrm{N}+\mathrm{HNAN} \mathrm{N})
\end{aligned}
$$

where PON was particulate organic nitrogen. Lee \& Fuhrman (1987) found, on average, that $53 \%$ of bacteria were retained by GF/F filter, but Middelboe et al. (1992), Kroer (1993) and Bratbak (1985) found percentages of 97,60 to 93 and $99.7 \%$, respectively. As particle content and volume filtered were large, bacteria were considered to be mostly retained by the GF/F filter used for PON analysis.

From initial nitrogen stocks in this batch and Eq. (1), a theoretical total nitrogen accumulation rate can be calculated. Total nitrogen in the inflow coming from the axenic Phaeodactylum tricornutum culture is calculated as $P$. tricornutum $\mathrm{N}+$ DIN (dissolved inorganic

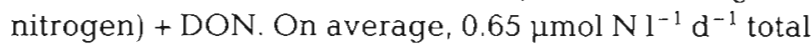
nitrogen should accumulate in the microcosm. The results (Fig. 5) showed high variations, and even sometimes a decrease in concentration of total nitrogen. Nevertheless, an average total nitrogen increase of

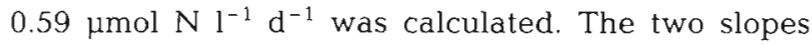
were not statistically different (Student's t-test) and confirmed negligible (or reversible on the time scale studied) wall fixation, whatever the nitrogen form, during the $26 \mathrm{~d}$ of the experiment.

DON represented 32 to $72 \%$ of the total nitrogen (average $56 \%$ ). Accumulated ammonium in this batch, even during the high regeneration phase at Day 24 , was always less than $20 \%$ of total nitrogen. The entire biotic compartment (bacteria, flagellates and ciliates) pooled together constituted an average of $15 \%$ of total nitrogen, with a peak at $36 \%$ on Day 24 . The maximal contribution of ciliates, flagellates or bacteria to total nitrogen was $15 \%$ (on Day 12), 23\% (on Day 24), and $11 \%$ (on Day 14 ), respectively.

In an attempt to obtain better information on nitrogen fluxes between each of the compartments, daily corrected variations were calculated, in nitrogen units, for each 'box' of the microcosm. A nitrogen budget was compiled, for the whole experiment (Days 2 to 26), and also for defined time intervals: Phase I, Days 2 to 11
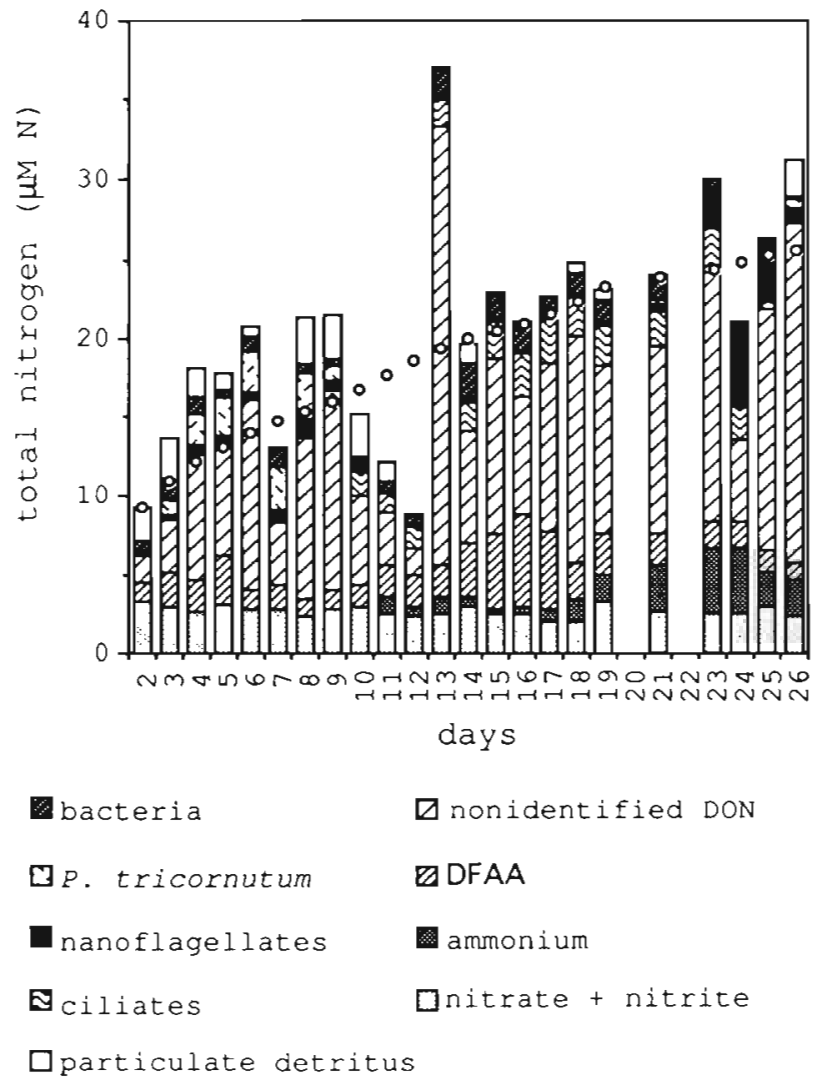

Fig. 5. Total nitrogen ( $\mu \mathrm{M} N$ ). Bars: values estimated with addition of all nitrogen forms measured during the experiment (see text for conversion factors); circles: theoretical total nitrogen accumulation

(phase of exclusive diet on Phaeodactylum tricornutum for the ciliate); Phase II, Days 11 to 16 (alternative diet for the ciliate growth); Phase III, Days 16 to 24 (nanoflagellate increase); and Phase IV, Days 24 to 26 (senescence phase of ciliates, decrease in nanoflagellate numbers).

Over the whole experiment, the nitrogen budget was almost balanced (Table 1, Days 2 to 26), i.e. total $N$ was conservative. Most of the nitrogen that disappeared was Phaeodactylum tricornutum nitrogen, while most of the nitrogen produced in the microcosm was nonidentified DON.

On shorter time scales, total nitrogen in the compartments which disappeared was not balanced by equivalent nitrogen production in other compartments. In Phases I and III, the total nitrogen that disappeared was greater, in terms of absolute values, than the total nitrogen produced during these periods. In contrast, in Phases II and IV, the total nitrogen pool produced was larger than that consumed (Table 1). Thus, a delay occurred between consumption and production. This delay was observed twice, giving a nearly balanced nitrogen budget when Phases I and II (2 to $16 \mathrm{~d}$ ) and 
Phases II and III (16 to $26 \mathrm{~d}$ ) were considered together (Table 1).

The nitrogen budget, as calculated, could be misinterpreted depending on the possible range of each of the conversion factors used to establish it. Thus, I examined the results of using extreme values cited in the literature to see if the uncouplings observed in the nitrogen budget were robust or if they depended on the conversion factors. The minimum and maximum values of the conversion factors used for each microorganism were as follows:

(1) Bacteria: $2.5 \mathrm{fg} \mathrm{N}$ cell-1 ${ }^{-1}\left[10 \mathrm{fg} \mathrm{C} \mathrm{cell}^{-1}\right.$ (Lancelot \& Billen 1984) and $C / N$ ratio $=4]$ and $30 \mathrm{fg} \mathrm{N}_{\text {cell }}{ }^{-1}$ (Goldman et al. 1985).

(2) Ciliates: 80 (Fenchel \& Finlay 1983) and 220 (Børsheim \& Bratbak 1987) fg $\mathrm{C} \mu \mathrm{m}^{-3}$, no change in $\mathrm{C} / \mathrm{N}$ ratio.

(3) Nanoflagellates: (a) Modification of the $\mathrm{C} / \mu \mathrm{m}^{3}$ ratio: 80 and $220 \mathrm{fg} \mathrm{C} \mu \mathrm{m}^{-3}$, no change in $\mathrm{C} / \mathrm{N}$ ratio. (b) Modification of the average biovolume: 104 and $492 \mu^{3}$ (values corresponding to the largest and smallest categories of HNAN identified). I also changed the $\mathrm{C} / \mathrm{\mu m}^{3}$ ratio simultaneously for flagellates and ciliates.

Changing a coefficient that contributes to increasing ciliate nitrogen biomass reduced the uncoupling observed in the first (Phases I and II) and second (Phases III and IV) periods. By analogy, the effect of increasing the nanoflagellate nitrogen biomass was a reduction of the uncoupling observed in the second period (Phases III and IV). Opposite effects were observed when nitrogen contribution of HNAN or ciliate was decreased by the use of low biovolume or density. Modifying conversion factors never changed Table 1 significantly: the uncouplings between 'consumption' and 'production' observed were thus more convincingly demonstrated

\section{DISCUSSION}

\section{Trophic steps and transfers}

Phaeodactylum tricornutum is resistant to decomposition (Bonin et al. 1986), and this probably prevented the diatom from being lysed and decomposed by bacteria before ciliate predation occurred. In another experiment of the same type where $P$. tricornutum was submitted to bacterial decomposition (Van Wambeke 1994), 4 d were necessary to obtain the signs of bacterial decomposition such as bacterial attachment and exoproteolytic activity development. During epifluorescence counts, I observed no bacteria attached to algal cells, suggesting that ciliates ingested algae before their death or autolysis. Furthermore, during the first few days, the accumulation of $P$. tricornutum corresponded to its theoretical inflow, suggesting no bacterial degradation. Organic nitrogen enrichment from the inflow was composed of $85 \% P$. tricornutum and $15 \%$ DON release (Van Wambeke unpubl. data). Thus, released organic material from $P$. tricornutum in the first stage inflow constituted an alternative organic nitrogen source for bacterial growth. Strong variations

Table 1. Nitrogen budget in the degrading stage. Daily net variations of nitrogen compartments (nM N d $\mathrm{d}^{-1}$ ) are integrated for the entire experiment and for Phases I to IV. Positive values indicate production (Prod), negative values indicate consumption (Cons). The comparison of the totals in each column ( $\sum$ Prod, $\Sigma$ Cons) indicates either that the nitrogen budget is balanced, or that production or consumption is in excess. CV: coefficient of variation

\begin{tabular}{|c|c|c|c|c|c|c|c|c|c|c|c|}
\hline \multirow[t]{2}{*}{ Time Interval } & \multirow[t]{2}{*}{$\mathrm{CV}$} & \multicolumn{2}{|c|}{$\begin{array}{l}\text { Entire expt } \\
\text { Days } 2 \text { to } 26\end{array}$} & \multicolumn{2}{|c|}{$\begin{array}{c}\text { Phase } 1 \\
\text { Days } 2 \text { to } 11\end{array}$} & \multicolumn{2}{|c|}{$\begin{array}{c}\text { Phase } 2 \\
\text { Days } 11 \text { to } 16\end{array}$} & \multicolumn{2}{|c|}{$\begin{array}{c}\text { Phase } 3 \\
\text { Days } 16 \text { to } 24\end{array}$} & \multicolumn{2}{|c|}{$\begin{array}{c}\text { Phase } 4 \\
\text { Days } 24 \text { to } 26\end{array}$} \\
\hline & & Prod & Cons & Prod & Cons & Prod & Cons & Prod & Cons & Prod & Cons \\
\hline Nitrate + nitrite & $1 \%$ & & -606 & & -695 & 34 & & 163 & & & -108 \\
\hline Ammonium & $5 \%$ & 2323 & & 1024 & & & -599 & 3706 & & & -1808 \\
\hline DFAA & $15 \%$ & & -120 & 450 & & 3932 & & & -4071 & & -431 \\
\hline Nonidentified DON & $10 \%$ & 13581 & & & -2239 & 3512 & & & -3819 & 16127 & \\
\hline Ciliates & $15 \%$ & 612 & & 1284 & & 1719 & & & -286 & & -2105 \\
\hline Nanoflagellates & $15 \%$ & 967 & & & -114 & 21 & & 4984 & & & -3924 \\
\hline \multicolumn{12}{|l|}{ Phaeodactylum } \\
\hline tricornutum & $15 \%$ & & -16990 & & -5733 & & -3990 & & -6270 & & -997 \\
\hline Bacteria & $15 \%$ & & -130 & & -28 & 1103 & & & -996 & & -209 \\
\hline Particulate detritus & $32 \%$ & 636 & & & -587 & & -823 & & -349 & 2395 & \\
\hline$\sum$ Prod, $\sum$ Cons & & 18119 & -17846 & 2758 & -9396 & 10321 & -5412 & 8504 & -15442 & 18522 & -9582 \\
\hline \multirow[t]{2}{*}{ Budget } & & \multicolumn{2}{|c|}{ Balanced } & \multicolumn{2}{|c|}{ Excess Cons } & \multicolumn{2}{|c|}{ Excess Prod } & \multicolumn{2}{|c|}{ Excess Cons } & \multicolumn{2}{|c|}{ Excess Prod } \\
\hline & & & & \multicolumn{4}{|c|}{ Phases I and II } & \multicolumn{4}{|c|}{ Phases III and IV } \\
\hline \multirow{2}{*}{\multicolumn{4}{|c|}{$\begin{array}{l}\sum \text { Prod, } \sum \text { Cons } \\
\text { Budget }\end{array}$}} & Prod $=$ & $1 \overline{3079}$ & Cons $=$ & -14808 & Prod $=$ & 27026 & Cons $=$ & -25024 \\
\hline & & & & \multicolumn{4}{|c|}{ Balanced } & \multicolumn{4}{|c|}{ Balanced } \\
\hline
\end{tabular}


of DON and DFAA nitrogen between Days 12 and 16 , during $P$. tricornutum predation, suggested transitory uncouplings between protein hydrolysis of egested material and bacterial assimilation of monomeric byproducts. Consequently, it could be assumed that bacterial growth was sustained mainly by the by-products from ciliate digestion: excretion and egestion of partially hydrolyzed contents of digestive vacuoles.

It appeared that heterotrophic nanoflagellates rapidly constituted an alternative prey for the ciliate. Two points support this hypothesis.

(2) The HNAN population increased at the end of the experiment concomitantly with a drastic decrease in ciliate abundance. It is reasonable to suppose that this HNAN population, stabilized previously with low abundance, was preyed on as soon as it reproduced.

(2) The size class that was responsible for most of the HNAN increase at the end of the experiment corresponded to an $8 \times 5 \mu \mathrm{m}$ ellipsoid of $104 \mu^{3}$. This population had an average biovolume twice that of Phaeodactylum tricornutum biovolume, but was more spherical. These 2 prey categories were about the same size, and could be used simultaneously by the ciliate without a noticeable biovolume change of this predator.

The ciliate decrease observed at the end of the experiment was not initiated by predation (no organisms of a larger size were present). A sudden lysis of the cells could be an explanation, as reflected by concomitant strong DON increase. Lysis could result from virus attack or a genetic constraint of the ciliate. In the degrading stage, the ciliate population was strongly controlled by food resources. Thus, small changes of fluxes and/or concentration of these food resources could also play a role in the sudden decrease of the ciliate population. Nanoflagellates showed a succession of 2 modes of control: top-down at the beginning (by ciliate predation) and bottom-up after the sudden lysis of the ciliates at the end of the experiment.

\section{Nitrogen budgets}

DON is, in the degrading stage, the major constituent of nitrogen identified. In natural environments, DON varies from 3 to $10 \mu \mathrm{M} N$ from surface oceanic to coastal waters (Sharp 1983, Jackson \& Williams 1985). DON is generally a poorly characterized group; only about $50 \%$ of its constituents have been identified (Billen 1984), and its turnover time in natural environments is difficult to determine (Jackson \& Williams 1985). For these reasons, the nitrogen budget in my experiment could help to explain sources of production and losses of DON in a limited microbial food web. But during some periods, nitrogen was produced or con- sumed in excess (Table 1). Three main reasons might explain the anomalies observed in the nitrogen budget of the degrading batch: (1) underestimation (by methodology) of the DON compartment; (2) inappropriate conversion factors; and (3) presence, in the microcosm, of an unidentified form of nitrogen.

Suzuki et al. (1985) suggested that total DON could be underestimated by classical oxidation methods (UV, persulfate), but it has been recognized recently that this is not the case (Suzuki 1993). In any case, such methodological underestimates would not be systematic here, as confirmed by the similarity between theoretical and observed total nitrogen accumulation slopes (see above).

The second hypothesis was ruled out because modifying the conversion factors did not suppress the anomalies observed in the nitrogen budget.

The third hypothesis is that a nitrogen form is transformed into an unidentified form (Phases I and III). This (or these) unidentified nitrogen form was afterwards transformed by physical or biological processes into another form which was recovered in identified 'produced' nitrogen.

Deficits of 'production' observed in Phases I and III corresponded to intensive grazing (I: ciliate on Phaeodactylum tricornutum III: HNAN on bacteria) associated with aggregate formation including bacteria, detritus and flagellates. However, deficits in the nitrogen budget were observed even if particulate detritus was included. In the aggregates were associated particulate nitrogen sensu stricto, composed of biotic forms and detritus, but also colloidal material released by excretion, leakage, hydrolysis and sloppy feeding. Because metazoans were absent, phagocytosis of prey by protozoans was the only predation process active in the microcosm. Sloppy-feeding sources were limited to egestion of partially degraded content of the digestive vacuoles.

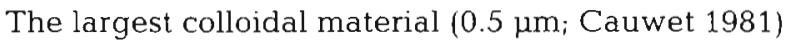
and some biotic material (small bacteria) can escape retention on a $\mathrm{GF} / \mathrm{F}$ filter but can be retained on a $0.2 \mu \mathrm{m}$ filter. Small bacteria could not account for the nitrogen deficits because their nitrogen is taken into account directly from epifluorescence counts. Moreover, the largest fraction of the leaked colloidal nitrogen material was not recovered, even when passing through $0.2 \mu \mathrm{m}$, since the filtration procedure for particulate compartment analysis (Whatman GF/F) and for dissolved compartment analysis (cellulose acetate Sartorius $0.2 \mu \mathrm{m}$ ) was not done successively.

Van der Walls forces and $\mathrm{H}-\mathrm{H}$ bindings are responsible for the complex structure of aggregates. But some of these bindings are unstable and may be broken during filtration. The chemical nature of the filter, the porosity of the filter and the total volume filtered 
(500 $\mathrm{mi}$ for $\mathrm{GF} / \mathrm{F}, 30 \mathrm{ml}$ for $0.2 \mu \mathrm{m}$ cellulose filter) were the principal reasons explaining a different behavior of this colloidal material: it passed through the GF/F glass fiber filter, and not through the $0.2 \mu \mathrm{m}$ cellulose filter. Leakage of amino acids is greater with $\mathrm{GF} / \mathrm{F}$ filters than with cellulose filters (Fuhrman \& Bell 1985).

UV irradiation probably hydrolyzed free viruses to DOM. If this was not the case, the viral nitrogen participation should be at maximum equivalent to that of bacteria and would not explain all the deficiencies observed. Nevertheless, the viral participation in colloidal material formation and in nitrogen-rich organic matter release is important (Proctor \& Fuhrman 1991). These processes were probably favored in the degrading batch of my experiment.

Whatever the true mechanism responsible for the lack of nitrogen recovery in Phases I and III, results showed that these unidentified nitrogen forms were unstable. They were recovered later (Phases II and IV) in an identified nitrogen form. Lack of nitrogen recovery has already been observed during phytoplankton succession, in conditions of nitrogen excess (Van Wambeke \& Bianchi 1990). Transitory accumulation of nitrogen colloids was the most probable explanation for the observed deficits.

One could question such DON accumulation compared to the low ammonium concentrations observed. Considering the low $\mathrm{C} / \mathrm{N}$ ratio of the fresh phytoplanktonic material in the inflow, and gross growth efficiencies of 23 to $43 \%$ obtained for the ciliate, nitrogen regeneration certainly occurred. Unfortunately, neither ammonium fluxes (uptake, regeneration) nor ammonium concentrations before Day 11 were measured. Net concentration changes after Day 10 suggested large ammonium regeneration only during the increase in HNAN biomass. Assuming high ammonium regeneration before HNAN increase implies counterbalanced sources of ammonium uptake, as the concentrations observed between Days 11 and 17 were low. Goldman et al. (1987a) showed evidence of significant dark uptake of $\mathrm{NH}_{4}^{+}$by nitrogen-limited phytoplankton prey. In the degrading stage, the nitrogenreplete Phaeodactylum tricornutum cells probably did not take up ammonium in the dark. HNAN and ciliates used prey with low $\mathrm{C} / \mathrm{N}$ ratios and were net nitrogen regenerators. Since no information is available on the DOM C/N ratio, the role of organotrophic bacteria in the nitrogen flux is unclear. In my experiment, in which food supply was very large, egestion of nitrogen-rich, only partially degraded ciliate by-products was certainly enhanced (Jumars et al. 1989, Nagata \& Kirchman 1992). In such conditions heterotrophic bacteria probably act as nitrogen regenerators (Billen 1984, Wheeler \& Kirchman 1986, Goldman et al. $1987 b)$. As confirmed by the nitrogen budget, DON constituted an important source of regenerated nitrogen for the ciliates. In laboratory studies, DOM production by protozoans has already been observed: dissolved organic carbon (Caron et al. 1985, Taylor et al. 1985), but also DON, i.e. DFAA (Andersson et al. 1985), DFAA and combined amino acids (Nagata \& Kirchman 1991). In a field study, Bronk \& Glibert (1993) demonstrated feeding-induced release of high weight DON in the $<202 \mu \mathrm{m}$ fraction. In my experiment, bacterial biomass was maintained by top-down control and was not limited by substrate. Consequently, the DON byproducts of the ciliates accumulated in the microcosm, and were even detected with net variations of concentration.

\section{CONCLUSIONS}

Two-stage sea-water cultures are of interest for separation of production and fate of phytoplankton detritus in the microbial food web. The number of trophic steps present in the mixed assemblage is unknown, and further experiments conducted with specific protozoan consumers would help to explore the different sources of DON. Nevertheless, the nitrogen budgets in the successive phases of this experiment revealed the temporary importance and turnover of colloidal nitrogen. Excess of food supply strongly enhanced the participation of DON in the ciliate nitrogen losses. Ciliate production was maintained because this Phaeodactylum tricornutum grazer was also able to feed on bacterivorous nanoflagellates and probably, to a lesser extent, on bacteria. Growth of the nanoflagellates depended on a detritivorous pathway created by the ciliate by-products, including partially degraded $P$. tricornutum cells egested with digestive vacuoles. Such high release of DOM by ciliates corresponded to a strategy for diversifying and damping the variations of its food sources. The reason for sloppy feeding by ciliates could be, apart from efficiency of digestion (Jumars 1989), the long-term survival of the ciliate's own progeny.

Acknowledgements. I am grateful to B. Berland and D. Arlhac for providing the axenic strain of Phaeadactylum tricornutum, and P. Raimbault and P. David for technical assistance with the Technicon Analyzer and UV apparatus. I thank 3 anonymous reviewers for comments on the manuscript.

\section{LITERATURE CITED}

Andersson A, Lee C, Azam F, Hagström § (1985) Release of amino acids and inorganic nutrients by heterotrophic marine microflagellates. Mar Ecol Prog Ser 23:99-106

Armstrong FA, Williams PM, Strickland JD (1966) Photooxidation of organic matter in seawater by ultra-violet 
irradiation, analytical and other applications. Nature 211 : 481-483

Azam F, Fenchel T, Field JG, Gray JS, Meyer-Reil LA, Thingstad $F$ (1983) The ecological role of water-column microbes in the sea. Mar Ecol Prog Ser 10:257-263

Baines SB. Pace ML (1991) The production of dissolved organic matter by phytoplankton and its importance to bacteria: patterns across marine and freshwater systems. Limnol Oceanogr 36:1078-1090

Billen G (1984) Heterotrophic utilization and regeneration of nitrogen. In: Hobbie JE, Williams PJ leB (eds) Heterotrophic activity in the sea. Plenum Press, New York, p 313-355

Bonin DJ, Droop MR, Maestrini SY, Bonin MC (1986) Physiological features of the six best microalgae to be used as ecological indicators in sea-water. Cryptogam Algol 7 23-83

Børsheim KY, Bratbak G (1987) Cell volume to cell carbon conversion factors for a bacterivorous Monas sp. enriched from sea water. Mar Ecol Prog Ser 36:171-175

Bratbak G (1985) Bacterial biovolume and biomass estimations. Appl environ Microbiol 49:1488-1493

Bronk DA, Glibert PM (1993) Contrasting patterns of dissolved organic nitrogen release by two size fractions of estuarine plankton during a period of rapid $\mathrm{NH}_{4}{ }^{+}$consumption and $\mathrm{NO}_{2}{ }^{-}$production. Mar Ecol Prog Ser 96:291-299

Caron DA, Goldman JC, Andersen OK, Dennet MR (1985) Nutrient cycling in a microflagellate food chain: II. Populations dynamics and carbon cycling. Mar Ecol Prog Ser 24:243-254

Cauwet G (1981) Non living particulate matter. In: Duursma EK, Dawson R (eds) Marine organic chemistry, evolution, interaction and chemistry of organic matter in seawater Oceanography series 31. Elsevier, Amsterdam, p 71-89

Cole JJ, Findlay S, Pace ML (1988) Bacterial production in fresh and saltwater ecosystems: a cross-system overview. Mar Ecol Prog Ser 43:1-10

Fenchel T, Finlay BJ (1983) Respiration rates in heterotrophic, free living protozoa. Microb Ecol 9:99-122

Fuhrman JA, Bell TM (1985) Biological considerations in the measurement of dissolved free amino acids in sea water and implications for chemical and microbiological studies Mar Ecol Prog Ser 25:13-21

Glibert PM (1982) Regional studies of daily, seasonal, and size fraction variability in ammonium remineralization. Mar Biol 70:209-222

Glibert PM (1988) Primary productivity and pelagic nitrogen cycling. In: Blackburn $\mathrm{TH}$, Sørensen J (eds) Nitrogen cycling in coastal marine environments. 1988 SCOPE John Wiley \& Sons, New York, p 3-31

Goldman JC, Caron DA, Andersen OK, Dennet MR (1985) Nutrient cycling in a microflagellate food chain: I. Nitrogen dynamics. Mar Ecol Prog Ser 24:231-242

Goldman JC, Caron DA, Dennet MR (1987a) Nutrient cycling in a microflagellate food chain: IV. Phytoplanktonmicroflagellate interactions. Mar Ecol Prog Ser 38:75-87

Goldman JC, Caron DA, Dennet MR (1987b) Regulation of gross growth efficiency and ammonium regeneration in bacteria by substrate $\mathrm{C} / \mathrm{N}$ ratio. Limnol Oceanogr 32 $1239-1252$

Güde $H$ (1991) Influence of phagotrophic processes on the regeneration of nutrients in two-stage continuous culture system. Microb Ecol 11:193-204

Hermin MN, Daumas RA, Drogue N (1986) Transferts d'acides aminés dans un système eau-sédiment: étude préliminaire en milieu expérimental. In: Beucher et al (eds) Deuxième Colloque International de Bactériologie Marine, CNRS Brest, 1-5 oct 1984, Actes de Colloques
Vol 3. IFREMER, Brest, $\mathrm{p}$ 61-72

Jackson GA, Williams PM (1985) Importance of dissolved organic nitrogen and phosphorus to biological nutrient cycling. Deep Sea Res 32:223-235

Jumars PA, Penry DL, Baross JA, Perry MA, Frost BW (1989) Closing the microbial loop: dissolved carbon pathway to heterotrophic bacteria from incomplete ingestion, digestion and absorption in animals. Deep Sea Res 36:483-495

Karl DM, Tien G, Dore J, Winn C (1993) Total dissolved nitrogen and phosphorus concentrations at US-JGOFS station ALOHA: Redfield reconciliation. Mar Chem 41:203-208

Koike I, Tupas L (1993) Dissolved organic nitrogen in Northern North Pacific assessed by high temperature combustion method. Mar Chem 41:209-214

Kroer N (1993) Bacterial growth efficiency on natural dissolved organic matter. Limnol Oceanogr 38:1282-1290

Lancelot C, Billen G (1984) Activity of heterotrophic bacteria and its coupling to primary production during the spring phytoplankton bloom in the Southern Bight of the North Sea. Limnol Oceanogr 29:721-730

Lee S, Fuhrman JA (1987) Relationships between biovolume and biomass of naturally derived marine bacterioplankton. Appl environ Microbiol 53:1298-1303

Lindroth P. Mopper K (1979) High performance liquid chromatographic determination of subpicomole amounts of amino acids by precolumn fluorescence derivatization with o-phthaldialdehyde. Analyt Chem 51:1667-1674

Middelboe M, Nielsen B, Søndergaard M (1992 Bacterial utilization of dissolved organic carbon (DOC) in coastal waters - determination of growth yield. Arch Hydrobiol Beih Ergebn Limnol 37:51-61

Nagata T, Kirchman DL (1991) Release of dissolved free and combined amino acids by bacterivorous marine flagellates. Limnol Oceanogr 36:433-443

Nagata T, Kirchman DL (1992) Release of dissolved organic matter by heterotrophic protozoa: implications for microbial foodwebs. Arch Hydrobiol 35:99-109

Paasche E, Kristiansen S (1982) Ammonium regeneration by microzooplankton in the Oslofjord, Norway. Mar Biol 69:55-63

Porter KG, Feig YS (1980) The use of DAPI for identifying and counting aquatic microflora. Limnol Oceanogr 25:943-948

Proctor LM, Fuhrman JA (1991) Role of viral infection in organic particle flux. Mar Ecol Prog Ser 69:133-142

Sharp JH (1983) The distributions of inorganic nitrogen and dissolved and particulate organic nitrogen in the sea. In: Carpenter EJ, Capone DG (eds) Nitrogen in the marine environment. Academic Press, London, p 1-35

Sherr EB, Sherr BF (1983) Double staining epifluorescence technique to assess FDC and bacteriovory in natural populations of heterotrophic microprotozoa. Appl environ Microbiol 46:1388-1393

Strickland JD, Parsons TR (1972) A practical handbook of seawater analysis. Bull Fish Res Bd Can 167:1-310

Suzuki Y (1993) On the measurements of DOC and DON in seawater. Mar Chem 41:287-288

Suzuki Y, Sugimura Y, Ito T (1985) A catalytic oxidation method for the determination of total nitrogen dissolved in seawater. Mar Chem 16:83-97

Taylor GT, Ituriaga R, Sullivan CW (1985) Interactions of bactivorous grazers and heterotrophic bacteria with dissolved organic matter. Mar Ecol Prog Ser 23:129-141

Turley CM, Newell RC, Robins DB (1986) Survival strategies of two small marine ciliates and their role in regulating bacterial community structure under experimental conditions. Mar Ecol Prog Ser 33:59-70

Van Wambeke F (1994) Influence of phytoplankton lysis or 
grazing on bacterial metabolism and trophic relationships Microb Ecol 27:143-158

Van Wambeke F, Bianchi MA (1990) Effect of organic nitrogen enrichments on marine planktonic networks and heterotrophic bacterial potential. Mar Ecol Prog Ser 63:17-25 Weisse T, Muller $\mathrm{H}_{1}$ Pinto-Cohelo RM, Schweizer A, Sprong- mann D, Baldringer G (1990) Response of the microbial loop to the phytoplankton spring bloom in a large prealpine lake. Limnol Oceanogr 35:781-794

Wheeler PA, Kirchman DL (1986) Utilization of inorganic and organic nitrogen by bacteria in marine systems. Limnol Oceanogr 31:998-1009 